\title{
Perception of Students towards the Offline and Online Modes of Learning during COVID-19 Lockdown
}

\author{
Aniketa Horo $^{1 *}$, Nupur Biswas ${ }^{2}$ and Jagruti Das ${ }^{3}$ \\ ${ }^{1}$ Department of Economics and Sociology, Punjab Agricultural University, \\ Ludhiana-141004, India \\ ${ }^{2}$ Department of Extension Education, Bihar Agricultural University, Sabour-813210, India \\ ${ }^{3}$ Division of Economics, Statistics and Management, ICAR-National Dairy Research Institute, \\ Karnal-132001, India \\ *Corresponding author
}

\section{Ke y w o r d s \\ Virtual education, COVID-19 \\ lockdown, India, Likert Scale \\ Article Info \\ Accepted: \\ 04 August 2020 \\ Available Online: \\ 10 September 2020}

\section{A B S T R A C T}

Going to a concrete classroom and acquiring knowledge followed by appearing for final examinations has been an age-old practice. But the outbreak of COVID-19 has changed the traditional educational system. All the educational activity shifted to the virtual platform with the classes and examinations being conducted online, either via Google forms or through personal interviews. It could only happen due to the increased adoption rate of smart-phones and internet connections among the common masses. Several online platforms like Google Meet, Cisco Webex, Zoom were used by the educational institutions to serve the purpose. The seminars and conferences were also cancelled due to the pandemic and instead webinars were conducted. The major challenge for the online learning is the limitation of internet connection in the families, as the number of children in the family may supersede the number of internet connections. Another problem that has surfaced is that students of private schools can afford the expensive internet connection but students of government school cannot bear to do so, therefore the public education system of India has collapsed during the nation-wide lockdown period. The verdict of Supreme Court regarding the cancellation of remaining board exams had imparted mixed feelings among the student fraternity but the board results has emerged as a ray of hope for them. These underlying issues attracted the authors attention to carry out this research and deduce results about the student's perception towards the traditional and virtual mode of learning. The concluding results state that students wish for a combination of online and offline mode of learning in the times to come.

\section{Introduction}

The nationwide lockdown impacted the normal life of everyone; all the educational institutes, religious places, offices, transportation facilities were prohibited. Work from home, online classes, social distancing, compulsory use of masks and sanitizers became a norm for the public. Although learning is a life-long process but education gained through institutional sources requires a systematic course of study resulting in 
awarding a degree. Prior to the outbreak of COVID-19, it was mandatory for the students to attend offline classes, gain knowledge, prepare assignments and then appear for the offline examinations conducted by their respective institutes. But, the complete lockdown forced the people to stay indoors, thereby completely barring the students from going to their schools/ colleges. Government of India announced the nationwide lockdown on $22^{\text {nd }}$ March 2020, on one hand where most of the schools were either carrying out their final-term examinations or were planning to resume the next session while on the other hand, colleges and universities were half-way through their semesters. The students who were impacted the most were the ones appearing for $10^{\text {th }}$ and $12^{\text {th }}$ board exams. Later the students till $9^{\text {th }}$ standard were promoted based on internal assessment and even the Supreme Court permitted the CBSE to cancel the pending examinations of $10^{\text {th }}$ and $12^{\text {th }}$. Classrooms were shifted to virtual platforms like Google classroom, Zoom, Google meet, Cisco Webex, etc. in order to continue the teaching-learning process.

The seminars and conferences scheduled during the time-period was also shifted in these virtual space where students, experts and stakeholders of different fields came together for exchange of knowledge. Sun \& Chen (2016) reviewed 47 published studies on online teaching and learning since 2008.

They concluded that effective online instruction is dependent upon well-designed course content, motivated interaction between the teachers and learners, well-prepared and fully-supported instructors, creation of a sense of online learning community and rapid advancement of technology. The current study was taken up with the objective to analyze the perception of students towards the online and offline modes of education.

\section{Materials and Methods}

The data was collected and tabulated during the national lockdown period, for which a Google form was prepared for the students of schools and colleges throughout the country and the link was sent to them via various social media platforms. Altogether 190 responses were duly recorded and tabulated on the Google Drive. In order to study the attitude of students towards the online and offline modes of study, with 5 point Likert Scale (1932) was used, i.e. strongly disagree, disagree, neutral, agree, strongly agree. The link sent for data collection was https://forms.gle/DA8W23SvDMQ8X8wdA.

\section{Results and Discussion}

According to the perusal of table 1, the highest number of respondents was from the age-group of 16-25 years followed by 26-35 years. It is clear that most of the respondents were research students and majority of them being females $(52.67 \%)$.

In this survey, 10 questions each for studying the perception of students towards the online and offline mode were prepared, the answers to which are described in the following figures 1 and 2 .

Figures 1 and 2 were the results of the student's attitude towards the traditional, offline mode of learning wherein it was clear that practical classes supplemented the theory classes which is not possible through the online classes as it does not allows hands-onlearning. Students find that classroom teaching helps them to understand better, memorize better and interact better.

Majority of the respondents agree that an online course should be made mandatory for the students. It was found that only $8.4 \%$ of the respondents did not attend any online class/webinar during the lockdown while 
$55.8 \%$ of the respondents did not participate in any online lectures before the lockdown, this indicates that lockdown period has lead to an increase of $47.4 \%$ in the participation of the online classes (Table 2).

Table.1 Age-group of respondents of the study

\begin{tabular}{|l|c|c|}
\hline S. No. & Age-group (in years) & No. of respondents \\
\hline $\mathbf{1 .}$ & $5-15$ & 6 \\
\hline $\mathbf{2 .}$ & $16-25$ & 115 \\
\hline $\mathbf{3 .}$ & $26-35$ & 66 \\
\hline $\mathbf{4 .}$ & $>35$ & 3 \\
\hline & Total & $\mathbf{1 9 0}$ \\
\hline
\end{tabular}

Table.2

\begin{tabular}{|c|c|c|c|c|c|}
\hline Questions & $\begin{array}{l}\text { Strongly } \\
\text { Agree }\end{array}$ & Agree & Neutral & Disagree & $\begin{array}{l}\text { Strongly } \\
\text { Disagree }\end{array}$ \\
\hline $\begin{array}{l}\text { I find the offline lectures are } \\
\text { more interesting }\end{array}$ & 44.2 & 33.2 & 13.7 & 5.8 & 3.2 \\
\hline $\begin{array}{l}\text { I find there is more } \\
\text { concentration in study during } \\
\text { offline lectures }\end{array}$ & 50.5 & 30 & 13.2 & 4.7 & 1.6 \\
\hline $\begin{array}{l}\text { I find materials are easily } \\
\text { accessible during the offline } \\
\text { lectures }\end{array}$ & 29.5 & 36.8 & 20 & 11.6 & 2.1 \\
\hline $\begin{array}{l}\text { I find there is more interaction } \\
\text { with the teachers during the } \\
\text { offline lectures }\end{array}$ & 63.2 & 23.2 & 5.3 & 6.8 & 1.6 \\
\hline $\begin{array}{l}\text { I find that practical classes } \\
\text { supplement the theory classes }\end{array}$ & 58.4 & 27.4 & 7.4 & 5.3 & 1.6 \\
\hline $\begin{array}{l}\text { I find there is an increase in my } \\
\text { performance during the offline } \\
\text { lectures }\end{array}$ & 36.3 & 31.1 & 18.4 & 12.1 & 2.1 \\
\hline $\begin{array}{l}\text { I find I am less active during the } \\
\text { study during the offline lectures }\end{array}$ & 7.9 & 20 & 20 & 43.7 & 8.4 \\
\hline $\begin{array}{l}\text { I find I am busy in other work } \\
\text { more than study during the } \\
\text { offline lectures }\end{array}$ & 8.4 & 13.2 & 16.3 & 45.8 & 16.3 \\
\hline $\begin{array}{l}\text { I find I interact less with my } \\
\text { classmates in the class during } \\
\text { the offline lectures }\end{array}$ & 8.9 & 23.2 & 12.1 & 37.4 & 18.4 \\
\hline $\begin{array}{l}\text { I find my memorizing power is } \\
\text { increasing more day by day } \\
\text { during the offline lectures }\end{array}$ & 23.2 & 38.9 & 22.6 & 11.6 & 3.7 \\
\hline
\end{tabular}


Fig.1

\section{Course of study}

School $\square$ Bachelor's $\square$ Master's $\square$ Ph.D. $\square$ Others

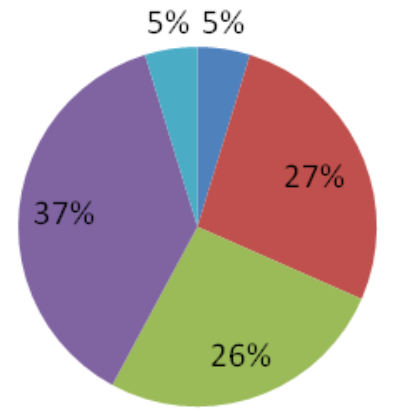

Fig.2

What do you feel should be the mode of teaching and learning in the post-COVID19 period? 190 responses

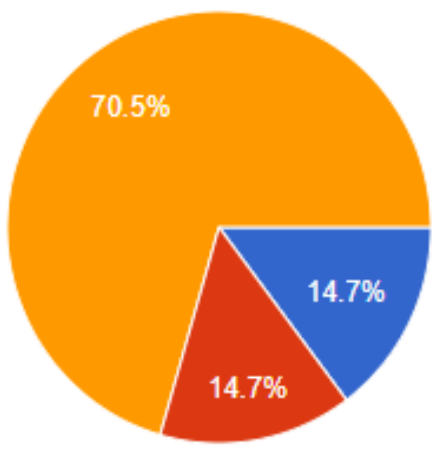

Entirely classroom teaching (offline).

Entirely online classes.

A combination of both the offline and online methods.

It was also revealed that $70.5 \%$ of the respondents feel that there should be a combination of offline and online mode for teaching and learning in the post-COVID19 period. Therefore, the concerned authorities should look into this matter and try to modify the classroom teaching for benefitting the students.

In conclusion, the respondents of the study have strongly agreed that traditional classroom teaching and learning process are more interesting and they could concentrate more on their studies with better interaction with their teachers and peers. They have even agreed that study materials are easily accessible leading to increase in memorizing power and better performance in the offline examinations. They have disagreed to the statements regarding being apathetic and distracted during the offline classes. The results have majority of the students $(70.5 \%)$ feel that there should be a combination of both offline and online modes of learning 
after the exemption of lockdown period. The results of the study somewhat reaffirms the findings of Nguyen (2015) where it was suggested that online learning is as effective as the traditional format and should be considered as the next stage of learning. Although there are short-comings with the online mode of education but nonetheless, efforts and effective policies can be made towards the digitalization of education in India. With the enforcement of New Education Policy in India, the education system will surely undergo revolutionary changes and will hopefully lead bright minds towards a bright future.

\section{References}

https://www.indiatoday.in/educationtoday/news/story/cbse-exam-case-in- supreme-court-all-you-need-to-knowwhat-happened-so-far-1692518-202006-25

Likert R. (1932) A technique for the measurement of attitudes. Archives of Psychology, 22: 5-55.

Nguyen T. (2015) The Effectiveness of Online Learning: Beyond No Significant Difference and Future Horizons. Merlot Journal of Online Learning and Teaching, 11(2) 309-319.

Sun, A., and Chen, X. (2016). Online education and its effective practice: A research review. Journal of Information Technology Education: Research, 15, 157-190.

\section{How to cite this article:}

Aniketa Horo, Nupur Biswas and Jagruti Das. 2020. Perception of Students towards the Offline and Online Modes of Learning during COVID-19 Lockdown. Int.J.Curr.Microbiol.App.Sci. 9(09): 183-187. doi: https://doi.org/10.20546/ijcmas.2020.909.023 